\title{
In vitro method for predicting the bioavailability of iron from Bathua (Chenopodium album) and Fenugreek (Trigonella foenum graecum) leaves in Indian cookies
}

\author{
R. Prasad, A. Gupta*, R. Parihar and K. Gangwar \\ Department of Foods and Nutrition, Ethelind School of Home Science, Sam Higginbottom, Institute of Agriculture, \\ Technology and Sciences, Allahabad-211007 (Uttar Pradesh), INDIA \\ *Corresponding author. E-mail: ami7823@gmail.com
}

Received: J uly 19, 2014; Revised received: 0 ctober 10, 2014; Accepted: November 26, 2014

\begin{abstract}
This study was considered to determine the nutritional composition and in vitro bioavailability of iron of the prepared food products. The in vitro bioavailability of iron was determined in fresh and dehydrated bathua (Chenopodium album) and methi (Trigonella foenum graecum) leaves (in the ratio of 1:1) and their based product i.e. Indian cookies (paratha and laddoo) by using thiocynate method at $\mathrm{pH} 1.35$ and 7.5 , using pepsin. At $\mathrm{pH} 1.35$ the soluble iron and ionizable iron were higher than $\mathrm{pH}$ 7.5. when $\mathrm{pH}$ was increased from 1.35-7.5 there was decreasing trend soluble as well as ionizable iron contents. There was highly significant $(F<0.05)$ difference between the control and treatments of products indicating that the addition of $20 \%$ of fresh and dehydrated leaves of bathua and methi improved the overall acceptability of products. The total iron content was found $11.69 \mathrm{mg} / 100 \mathrm{~g}$ in paratha incorporated with fresh GLVs whereas in vitro bioavailability of iron was found $2.16 \mathrm{mg} / 100 \mathrm{~g}$ in paratha. The total iron content was found $15.16 \mathrm{mg} / 100 \mathrm{~g}$ in laddoo incorporated with dehydrated GLVs whereas in vitro bioavailability of iron was found $2.78 \mathrm{mg} / 100 \mathrm{~g}$ in laddoo.
\end{abstract}

Keywords: Bioavailability, Chenopodium album, Iron, Trigonella foenum graecum

\section{INTRODUCTION}

Bioaccessibility or bioavailability (or biological availability) is the key to nutrient effectiveness, which is defined as the proportion of nutrient in the food that can be absorbed and utilized. Bioavailability of dietary iron is the proportion of iron that is actually available for the absorption and utilization by the body. Bioavailability of iron is known to be influenced by various dietary components, which include both dietary inhibitors and enhancers of absorption. Among inhibitors, phytic acid, tannins, dietary fibre and calcium are the most potent, while organic acids are known to promote iron absorption (Sandberg, 2002). Many studies have shown that addition of components like tomato or tamarind juice might be also partially responsible for increase in the available iron (Sathya et al., 2002 and Hemalatha et al., 2007). Green leafy vegetables are the most suitable foodstuffs for enriching dietary iron of the Indians. Though the leafy vegetables contain high total iron, the bioavailability of mineral varies. Vegetarian meals have a poor bioavailability of iron in addition to poor content which is also true for zinc. In vitro methods offer appealing protocol, as they are simple, rapid, low cost and provide insights not achievable in whole animal studies. Dehydration also makes them a concentrated source of vitamins and minerals and thus they become a very suitable "natural fortificant" (Joshi and Mathur, 2010). Fenugreek plant contains active constituents such as alkaloids, flavonoids, steroids, Saponins etc. It is an old medicinal plant. It has been commonly used as a traditional food and medicine. Fenugreek is known to have hypoglycemic, and hypocholesterolaemic, effects, Anti-inflammatory effects (Moradi and Moradi, 2013). According to Aggarwal and Khanna (2007) children receiving fortified supplementation with leaf powder concentrates have improved anthropometric indices and vitamin- A status. Dehydrated green leafy vegetables are also rich sources of iron and $\beta$ - carotene and can be used in lean season (Rao et al., 2005). Gupta et al. (2013) also observed the influence of dehydration on nutrient composition of Amaranthus gangeticus, Chenopodium album, Centella asiatica, Amaranthus tricolor and Trigonella foenum graecum. Fenugreek (T. foenum-graecum) leaves and seeds have been used extensively for medicinal purposes. Fenugreek seed is known to exhibit anti-diabetic and anti-nociceptive properties (Acharya et al., 2006). Bathua leaves (C. album Linn.) rich in micronutrients (Singh et al., 2007). It contains a mucilaginous fibre $(20 \%)$ and has a total fibre 
content of $50 \%$. It is a very rich source of calcium, beta carotene. The lower glycemic load after fenugreek leaves supplementation could be due to fibre which diminishes the absorption of carbohydrate to a point lower in the gut after colonic conversion (Bever et al., 2008). Therefore, present study was conducted for predicting the bioavailability of iron from Bathua (C. album) and Fenugreek (T. foenum graecum) leaves by in vitro method.

\section{MATERIALSAND METHODS}

Test materials: The present investigation was carried out in the Nutrition Research Laboratory, Department of Foods and Nutrition, Ethelind School of Home Science, Sam Higginbottom Institute of Agriculture, Technology and Science (SHIATS), Allahabad. Fresh leaves of Fenugreek, Bathua and other ingredients required for the experiment were collected from the local market of Allahabad district. The leaves were carefully clean, sort to remove defective one of the lots graded according to the size and colour. The dehydration of bathua and methi leaves was done through tray drying at $60-65^{\circ} \mathrm{C}$ for 15 hours (Fig.1.). The fenugreek and bathua leaves was utilized in the preparation of Indian cookies (Paratha incorporated by fresh leaves of bathua and methi in the ratio of 1:1 and Laddoo incorporated by dehydrated leaf powder of bathua and methi in the ratio of 1:1) with 4 replications of each product. For each product the basic recipes (control $\mathrm{T}_{0}$ ) have three variations $\mathrm{T}_{1}, \mathrm{~T}_{2}$, $\mathrm{T}_{3}$, respectively where the amount of fenugreek and bathua leaves was varied (Table 1). Sensory evaluation of the food products for their acceptability was done by a panel of judges. The score card based on the 9 point Hedonic Scale was used for sensory evaluation on the basis of evaluation of attributes like colour and appearance, texture, taste and flavour and overall acceptability (Srilakshmi, 2007).

Extraction of soluble and ionizable iron: Weighed food sample and homogenized cooked diet was first incubated with pepsin-HCL solution $(0.5 \%$ pepsin in $0.1 \mathrm{~N} \mathrm{HCL})$. In case of dry foods, $2 \mathrm{~g}$ of the food was mixed with $25 \mathrm{ml}$ of pepsin- HCL, and in case of homogenized diets they were diluted with an equal volume of pepsin- HCL mixture. The $\mathrm{pH}$ of mixture was adjusted to 1.35 with distilled HCL and incubated in a $100 \mathrm{ml}$ conical flask at $37^{\circ} \mathrm{C}$ in a metabolic shaker water bath for 90 minutes. At the end of this incubation, the contents of the flask were centrifuged at 3000 rpm for 45 minutes and the supernatant filtered through Whatman no. 44 filter paper, soluble and ionizable iron was determined in aliquots of the filterate at $\mathrm{pH} 1.35$ as mentioned below. In another aliquots $\mathrm{pH}$ was adjusted to 7.5 with $\mathrm{NaOH}$ and incubated at $37^{\circ} \mathrm{C}$ for 90 minute in a metabolic shaker water bath. At the end of this incubation period the contents of the flask were centrifuged at $3000 \mathrm{rpm}$ for 45 minutes, and the supernatant was filtered again. The filterate was used for the determination of soluble and ionizable iron.

Analytical methods

Total iron: The food material was dry ashed as described by the Association of Official Agriculture Chemists (AOAC, 2005) and total iron in the mineral solution was estimated by the Thiocynate method and was compared with that of a, a- dipyridyl method.

I onizable iron: Free form of iron in the filterate, which reacts with Potassium thiocynate to yield blue color of ferric thiocynate, obtained after incubation of foods at $\mathrm{pH} 1.35$ and 7.5, was determined colorimetrically as described by AOAC (2005). This form of iron corresponds to the ionizable iron.

Soluble iron: The soluble iron was determined by Tennat and Greenman (1969). The aliquot was digested with potassium permanganate to oxidize ferrous to ferric iron, decolorized with ascorbic acid and filtered. The iron content in filterate was determined by colorimetric method of thiocynate.

Bioavailability of iron: In vitro bioavailability of iron was estimated by using standard procedures (Narasinga and Prabhavathi, 1978).

Statistical analysis: Analysis of variance technique (ANOVA), t-test and critical difference statistical tests were used to analyze the data (Gupta and Kapoor, 2002). Values of different parameters are expressed as the mean \pm standard deviation.

\section{RESULTS AND DISCUSSION}

Nutritional composition of dehydrated B athua and $M$ ethi leaf powder in per 100g: Result shows that nutrient concentration per $100 \mathrm{~g}$ of the product increases in dehydrated bathua and methi leaf powder as compared to the values in fresh bathua and methi leaves. The Iron in dehydrated bathua and methi leaf powder per $100 \mathrm{~g}$ was 20.89 (Table 2), respectively. Singh et al. (2007) reported that iron and carotene contents of dehydrated bathua leaves $(27.48 \mathrm{mg} / 100 \mathrm{~g}$ and $14826 \mu \mathrm{g} / 100 \mathrm{~g}$, respectively) were 6-8 times higher than fresh leaves.

Nutritional composition of value added products in per 100g: Using the fresh and dehydrated fenugreek and bathua leaves the two value added products for each leaves respectively were prepared i.e. Indian cookies (paratha and laddoo) and to analyze the total iron content. Table 2 shows that iron content was high in laddoo $15.16 \mathrm{mg} / 100 \mathrm{~g}$ and in paratha was $11.69 \mathrm{mg} / 100 \mathrm{~g}$. Singh et al. (2007) studied that showed that iron content increased as the incorporation level of dehydrated bathua leaves increased in making paratha. $\mathrm{T}_{3}$ i.e. (15\% incorporation level) which was also acceptable at sensory score $6.62 \pm 0.11$ has got highest iron content i.e. $8.81 \mathrm{mg} / 100 \mathrm{~g}$.

In vitro bioavailability of iron: The in vitro bioavailability 
Table 1. Details of control and treatment combinations (Each time four replicates were taken).

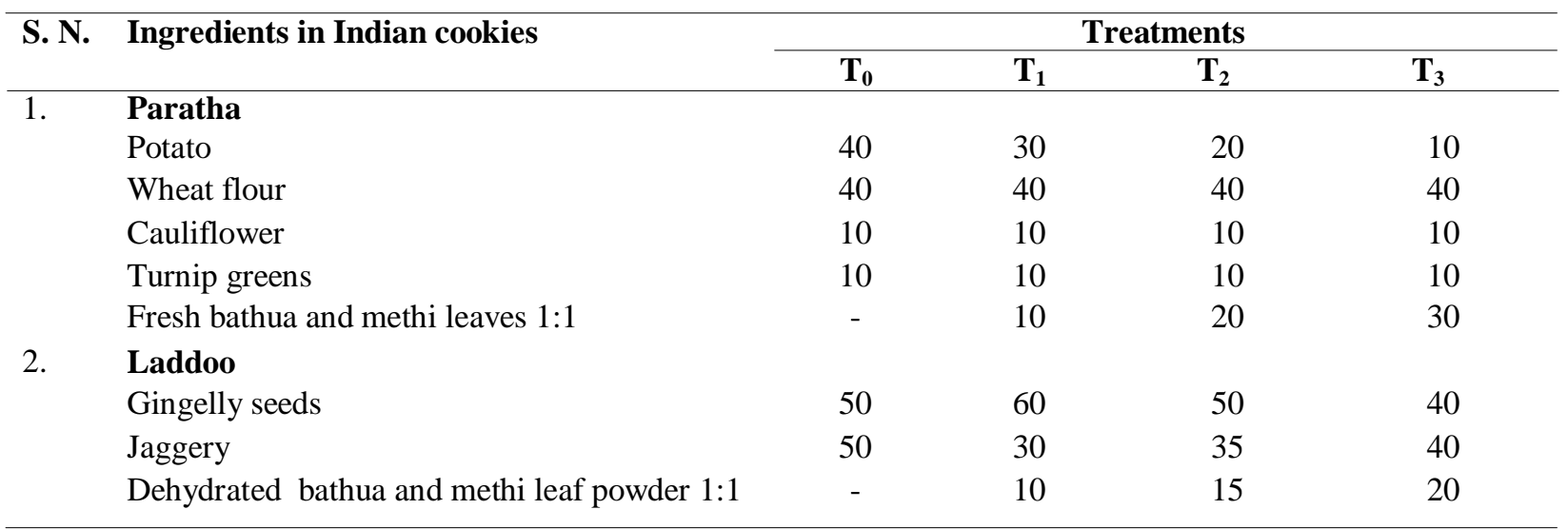

Paratha : Control $\left(\mathrm{T}_{0}\right)$ : prepared from potato, wheat flour, cauliflower and turnip greens; Treatments: $\left(\mathrm{T}_{1}\right)$ : prepared from potato, wheat flour, cauliflower, turnip greens and mixture of fresh leaves (bathua and methi 1:1) in a ratio of 30:40:10:10:10; $\left(\mathrm{T}_{2}\right)$ : prepared from potato, wheat flour, cauliflower, turnip greens and mixture of fresh leaves ( bathua and methi 1:1) in a ratio of 20:40:10:10:20; $\left(\mathrm{T}_{3}\right)$ : prepared from potato, wheat flour, cauliflower, turnip greens and mixture of fresh leaves (bathua and methi 1:1) in a ratio of 10:40:10:10:30. Laddoo: Control $\left(\mathrm{T}_{0}\right)$ : prepared from gingelly seeds and jaggery;Treatments $\mathrm{T}_{1}:$ prepared from gingelly seed, jaggery and mixture of dehydrated leaf powder (bathua and methi 1:1) in a ratio of 60:30:10; $\left(\mathrm{T}_{2}\right)$ : prepared from gingelly seed, jaggery and mixture of dehydrated leaf powder (bathua and methi 1:1) in a ratio of 50:35:15; $\left(\mathrm{T}_{3}\right)$ : prepared from gingelly seed, jaggery and mixture of dehydrated leaf powder (bathua and methi 1:1) in a ratio of 40:40:20.

Table 2. Iron content in dehydrated powder and value added food products incorporated with fresh and dehydrated green leafy vegetables bathua ( C. album) and fenugreek (T. foenum graecum).

\begin{tabular}{lc}
\hline Indian products & Iron $(\mathrm{mg} / 100 \mathrm{~g})$ \\
\hline $\begin{array}{l}\text { Dehydrated } \\
\text { bathua and methi leaf powder 1:1 }\end{array}$ & $20.89 \pm 0.75$ \\
$\begin{array}{l}\text { Paratha (Fresh bathua and methi } \\
\text { leaves 1:1) }\end{array}$ & $11.69 \pm 0.57$ \\
$\begin{array}{l}\text { Laddoo (Dehydrated } \\
\text { bathua and methi leaf powder 1:1) }\end{array}$ & $15.16 \pm 0.97$ \\
\hline
\end{tabular}

Mean \pm SD of 4 replicates sampled products of GLVs

of iron was determined in fresh bathua and methi leaves, fresh bathua and methi leaves based product paratha, dehydrated bathua and methi leaf powder and dehydrated bathua and methi leaf powder based product laddoo by using thiocynate method at variable $\mathrm{pH} 1.35$ to $7.5 \mathrm{using}$ pepsin at different concentration. Iron may become soluble or ionized when it comes in contact with $\mathrm{HCl}$ in stomach but when it enters the duodenum the $\mathrm{pH}$ becomes alkaline compared to gastric $\mathrm{pH}$, where much of the iron which is ionized at the acid $\mathrm{pH}$ becomes insoluble depending upon the factors present in the diet.

The total iron, soluble iron and ionizable iron was studied (Table 3). The soluble iron and ionizable iron was calculated at the $\mathrm{pH} 1.35$ and 7.5 , when the $\mathrm{pH}$ was increased from 1.35 to 7.5 , both the ionizable iron decreases in all the foods. The results revealed that at $\mathrm{pH} 1.35$ the soluble iron and ionizable iron contents were higher than $\mathrm{pH}$ 7.5. When $\mathrm{pH}$ was increased

Table 3. Effect of incorporation of fresh leaves and dehydrated bathua (C. album) and fenugreek (T. foenum graecum) at different levels on the bioavailability of iron at pH 1.35 and pH 7.5.

\begin{tabular}{|c|c|c|c|c|c|c|}
\hline \multirow[t]{2}{*}{ S.N. } & \multirow[t]{2}{*}{ Products } & \multirow{2}{*}{$\begin{array}{l}\text { Total iron } \\
\text { (mg/100g) }\end{array}$} & \multicolumn{2}{|c|}{$\mathrm{pH}=1.35$} & \multicolumn{2}{|c|}{$\mathrm{pH}=7.5$} \\
\hline & & & Soluble iron & $\begin{array}{l}\text { Ionizable } \\
\text { iron }\end{array}$ & Soluble iron & $\begin{array}{l}\text { Ionizable } \\
\text { iron }\end{array}$ \\
\hline \multirow[t]{2}{*}{1.} & $\begin{array}{l}\text { Fresh bathua and methi } \\
\text { leaves }\end{array}$ & 3.06 & $\begin{array}{c}1.84 \\
(60.13 \%)\end{array}$ & $\begin{array}{c}0.94 \\
(30.71 \%)\end{array}$ & $\begin{array}{c}1.77 \\
(57.84 \%)\end{array}$ & $\begin{array}{c}0.87 \\
(28.43 \%)\end{array}$ \\
\hline & $\begin{array}{l}\text { Fresh bathua and methi } \\
\text { leaves based product } \\
\text { Paratha }\end{array}$ & 11.69 & $\begin{array}{c}6.56 \\
(56.11 \%)\end{array}$ & $\begin{array}{c}3.63 \\
(31.05 \%)\end{array}$ & $\begin{array}{c}5.98 \\
(51.15 \%)\end{array}$ & $\begin{array}{c}3.56 \\
(30.45 \%)\end{array}$ \\
\hline \multirow[t]{2}{*}{2.} & $\begin{array}{l}\text { Dehydrated bathua and } \\
\text { methi leaf powder }(1: 1)\end{array}$ & 20.59 & $\begin{array}{c}10.25 \\
(61.78 \%)\end{array}$ & $\begin{array}{c}6.78 \\
(40.86 \%)\end{array}$ & $\begin{array}{c}8.24 \\
(40.01)\end{array}$ & $\begin{array}{c}4.65 \\
(22.58 \%)\end{array}$ \\
\hline & $\begin{array}{l}\text { Dehydrated bathua and } \\
\text { methi leaf powder } \\
\text { based product Laddoo }\end{array}$ & 15.16 & $\begin{array}{c}7.98 \\
(58.85 \%)\end{array}$ & $\begin{array}{c}5.12 \\
(33.77 \%)\end{array}$ & $\begin{array}{c}7.07 \\
(49.90 \%)\end{array}$ & $\begin{array}{c}4.89 \\
(32.25 \%)\end{array}$ \\
\hline
\end{tabular}


Table 4. Bioavailability of iron of the products prepared by incorporating fresh and dehydrated Bathua (C. album) and Fenugreek (T. foenum graecum) leaves (per 100g).

\begin{tabular}{llcccc}
\hline S. N. & Products & $\begin{array}{c}\text { Total I ron } \\
(\mathrm{mg} / 100 \mathrm{~g})\end{array}$ & $\begin{array}{c}\text { I onizable I ron } \\
(\mathrm{mg} / 100 \mathrm{~g})\end{array}$ & $\begin{array}{c}\text { I onizable } \\
\text { Iron }(\%)\end{array}$ & $\begin{array}{c}\text { In vitro } \\
\text { available I ron }\end{array}$ \\
\hline 1. & $\begin{array}{l}\text { Fresh Bathua and Methi leaves (3) } \\
\text { Fresh Bathua and Methi leaves }\end{array}$ & $* 3.06 \pm 0.69$ & $0.87 \pm 0.19$ & $28.43 \pm 2.21$ & $0.89 \pm 0.22$ \\
& $\begin{array}{l}11.69 \pm 0.89 \\
\text { based product Paratha (3) }\end{array}$ & $3.56 \pm 0.27$ & $30.45 \pm 2.40$ & $2.16 \pm 0.31$ \\
2. & $\begin{array}{l}\text { Dehydrated Bathua and Methi leaf } \\
\text { powder (3) }\end{array}$ & $20.59 \pm 0.43$ & $4.65 \pm 0.30$ & $22.58 \pm 1.06$ & $2.67 \pm 0.34$ \\
& $\begin{array}{l}\text { Dehydrated Bathua and Methi leaf } \\
\text { powder based product Laddoo (3) }\end{array}$ & $15.16 \pm 0.65$ & $4.89 \pm 0.34$ & $32.25 \pm 2.10$ & $2.78 \pm 0.38$ \\
\hline
\end{tabular}

Values in parentheses indicate the number of samples; Values are means, \pm S.E. of three independent replicates. In vitro available iron based on prediction equation for iron absorption using percent ionizable iron at $\mathrm{pH} 7.5$ was calculated: $\mathrm{Y}=0.4827+0.4707 \mathrm{X}$, where $\mathrm{X}$ is percent ionizable iron at $\mathrm{pH} 7.5$. * Value of total iron of fresh bathua and methi leaves (3.06) referred from Gopalan et al., 2007; Nutritive value of Indian foods.

Green leafy vegetables

(Mature and free from insects and diseases)

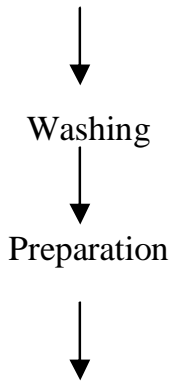

Spreading on flat aluminum trays

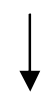

Tray drying at $60-65^{\circ} \mathrm{C}$ for 15 hours.

Dehydration till the moisture become $6-8 \%$

Grinding into powder

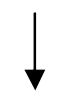

Storage

(At ambient temperature in dry place)

Fig. 1. Flow diagram of green leafy vegetable dehydration (Source: Srivastava and Kumar, 2002).

from 1.35-7.5 there was decreasing trend soluble as well as ionizable iron contents samples. The total iron content of fresh bathua and methi leaves, fresh bathua and methi leaves based product paratha, dehydrated bathua and methi leaf powder and dehydrated bathua and methi leaf powder based product laddoo were $3.06 \pm 0.69 \mathrm{mg} / 100 \mathrm{~g}, 11.69 \pm 0.89$ $\mathrm{mg} / 100 \mathrm{~g}, 20.59 \pm 0.43 \mathrm{mg} / 100 \mathrm{~g}$ and $15.16 \pm 0.65 \mathrm{mg} / 100 \mathrm{~g}$, respectively. It was found that the availability of iron increases significantly at $\mathrm{pH} 1.35$ and $\mathrm{pH}$ 7.5. Dehydrated bathua and methi leaf powder and dehydrated bathua and methi leaf powder based product laddoo contained more iron as compared with fresh bathua and methi leaves and fresh bathua and methi leaves based product paratha (Table 4) indicates that the range of total iron in the prepared products was $3.06-20.59 \mathrm{mg} / 100 \mathrm{~g}$. The dehydrated bathua and methi leaf powder has the highest score of total iron i.e. $20.59 \pm 0.43 \mathrm{mg} / 100 \mathrm{~g}$.

The soluble and ionizable iron was calculated at $\mathrm{pH}$ 1.35 (Table 3). The percent of soluble iron for prepared food items was different. The soluble iron at the $\mathrm{pH} 1.35$ was ranged from $1.84-10.25 \mathrm{mg} / 100 \mathrm{~g}$. Dehydrated bathua and methi leaf powder has the highest score of soluble iron i.e. $10.25 \mathrm{mg} / 100 \mathrm{~g}$. The ionizable iron at the $\mathrm{pH} 1.35$ ranged from 0.94-6.78 $\mathrm{mg} / 100 \mathrm{~g}$. Here also, the ionizable iron content was rich in dehydrated bathua and methi leaf powder.

Our results show values for iron concentration in prepared products similar to those found in the study performed by Singh et al. (2007) who have observed that iron content increased as the incorporation level of dehydrated bathua leaves increased in making paratha. These values were similar those reported by Das et al. (2005) who determined in vitro iron from six GLV's and amount of ionizable iron which was found to range from $30.22 \pm 1.10 \%$ in bachali (Basella alba) to $52.13 \pm 1.90$ percent of total iron in fenugreek leaves. However, the ionizable iron content varied from 0.55 $\mathrm{mg} / 100 \mathrm{~g}$ in bacchali to $1.75 \mathrm{mg} / 100 \mathrm{~g}$ in agathi.

Yadav and Sehgal (2002) reported that the iron content of bathua and spinach leaves was 20.63 and 26.54 $\mathrm{mg} / 100 \mathrm{~g}$, respectively on dry weight basis and also studied, in vitro and in vivo availability of iron from bathua and spinach leaves and found that iron contents of these green leafy vegetables varied from 20 percent to 26 percent (on dry weight basis) and in vitro availabilities of iron ranged from 2.79 to 3.03 percent. These leaves helped in increasing the haemoglobin level also. This study also supported the work of Bhavyashree, et al., 2009 who studied on In vitro accessibility of iron, and zinc from cereal based 
composite meals and ready to eat foods. Hemalatha et al. (2007) investigated bioaccessibility of iron and zinc from cereals and pulses consumed in India. The bioaccessibility of zinc and iron was lowest in sorghum (5.51\% and $4.13 \%$, respectively) and highest in rice $(21.4 \%$ and $8.05 \%$, respectively). Whereas in pulses it ranged from 1.77 to 10.2 per cent lowest in cowpea and highest in french beans. Gupta et al. (2006) investigated the relative influence of oxalic acid, phytic acid, tannin and dietary fibre on in vitro availability of iron from green leafy vegetables. Bioavailability of iron in 13 GLVs was estimated by equilibrium dialysis method. Singh and Kawatra (2006) studied on ionizable iron content of products viz., pakora, vada, namakpara, kurmura biscuit and cake prepared with addition of fresh and dried powder of amaranthus leaves. Ionizable iron content of products ranged from 1.3 in kurmura to $2.9 \mathrm{mg} / 100 \mathrm{~g}$ in biscuit prepared from dried leaves. Ionizable iron expressed as percent of total iron was highest in biscuit $(57.4 \%)$ followed by cake $(27.5 \%)$ and namakpara prepared with dried and fresh amaranthus leaves ( $25 \%$ and $23.7 \%$, respectively), pakora with fresh leaves $(19.3 \%)$, kurmura with dried leaves (16.1\%), vada $(16.2 \%)$ and kurmura with fresh leaves (22.4\%). This study also supported with Sahai and Gupta (2012) who studied on in vitro bioavailability of iron of the products prepared from the leaves of the weed, Indian Sorrel (Oxalis Corniculata). Indian sorrel leaves incorporated $10 \%, 20 \%$ and $30 \%$ into three recipes, peanut chutney, lemon drink and idli" using their standard ingredients. The iron content ranged between 27.05 to $60.55 \mathrm{mg} / 100 \mathrm{~g}$. The soluble and ionizable iron both were also calculated at the two different $\mathrm{pH}$ i.e.1.35 and 7.5, that ranged between 9.35-13.26 $\mathrm{mg} / 100 \mathrm{~g}$, 4.48-6.89 mg/100g, 8.02-12.03 mg/100g, $3.38-5.58 \mathrm{mg} / 100 \mathrm{~g}$, respectively. The highest iron content was found in peanut chutney. i.e. $60.55 \pm 20.58$.

\section{Conclusion}

It is concluded that incorporation of fresh leaves and dehydrated bathua and methi leaf powder in Indian cookies like paratha and laddoo are well acceptable based on sensory evaluation and nutrient concentration. Paratha and laddoo were rich in iron content. Bioavailability of iron was also tested and the dehydrated bathua and methi leaf powder has the highest amount of total iron, soluble iron and the ionizable iron $(\mathrm{pH} 1.35)$. Dehydrated bathua and methi leaf powder based product laddoo has the highest score in ionizable iron and in vitro availability iron at $\mathrm{pH} 7.5$ i.e. $4.89 \pm 0.34 \mathrm{mg} / 100 \mathrm{~g}$ and $2.78 \pm 0.38$, respectively. This method can be used to determine the extent to which availability of iron can be improved by manipulation of diets and used to predict iron absorption from diets and iron sources that are intended for use in prevention of iron deficiency anemia. Therefore, it is recommended that these green leafy vegetables should be included in the diets of general masses especially adolescent girls, who are prone to iron deficiency anaemia. Nutrition education programme should also emphasize the use of green leafy vegetables, which are inexpensive and can be used easily by community.

\section{ACKNOW LEDGEMENTS}

The authors are grateful to Prof. S. Sheikh, Dean of Ethelind school of Home-science and Prof. P. J. George, Department of Soil Science, Sam Higginbottom Institute of Agriculture, Technology and Sciences, Allahabad for the support during this course of study and their excellence technical assistance is gratefully acknowledged.

\section{REFERENCES}

Acharya, S, Srichamroen, A, Basu, S, Ooraikul, B. and Basu, T. (2006). Improvement in the neutraceutical properties of fenugreek (Trigonella foenum- graecum L) songklanakarin. J. Food Sci. Tech., 28 (1): 1-9.

Aggarwal, M. and Khanna, K. (2007). Impact of leaf powder concentrate representation Vitamin- A and iron status of children aged 1-3 years. Abstract: IX Asian Congress of Nutrition 23 rd $-27^{\text {th }}$ Feb (2003), New Delhi, India- 224.

AOAC (2005). Official methods of analysis of the association of official analytical chemists, $18^{\text {th }}$ Ed.

Bever, B.O; Zahand, G.R. Loper, M., Wolever, M. and Jenkins, A.J., (2008). Plants with hypoglycemic action", Diabetologia, 41:505-512.

Bhavyashree, S.H; Prakash, J; Platel, K. and Srinivasan, K. (2009). Bioaccessibility of minerals from cereal based composite meals and ready to eat foods. J. Food Sci. Tech., 46 (5): 431-435.

Das, P; Raghuramulu, N; and Rao, K.C. (2005). Determination of in vitro availability of iron from common foods. J. Human Ecol., 18 (1): 13-20.

Gopalan, C; Balasurmanianm, C.S. and Sastri Rama, V.B. (2007). Nutritive Value of Indian foods, $4^{\text {th }}$ edition printed by NINI- ICAR, pp.46-61.

Guéguen, L. and Pointillart, A., (2000). The bioavailability of dietary calcium. J. Am. Coll. Nutri., 19(2): 119S-136S.

Gupta, S.C. and Kapoor, U.K. (2002). Fundamentals of Applied Statistics, $2^{\text {nd }}$ Edition, Chand and Sons, 51- 85.

Gupta, S, Lakshmi, A.J. and Prakash Jamuna (2006). In vitro bioavailability of calcium and iron from selected green leafy vegetables. Journal of the Science of F ood and Agriculture, 86(13), 2147-2152.

Gupta, S; Gowari, B.S; Lakshmi, A.J. and Prakash Jamuna (2013). Retention of nutrients in GLV on dehydration. J. Food Science Technology,50 (5): 285-295.

Hemalatha, S, Platel, K. and Srinivasan, K. (2007). Zinc and Iron content and their bioaccessibility in cereals and pulses consumed in India. Food Chem., 102: 1328-1336.

Joshi, P. and Mathur, B. (2010). Preparation of value added products from the leaf powders of dehydrated less utilized green leafy vegetables. J ournal of Horticulture and Forestry, 2(9): 223 - 228.

Moradi, N. and Moradi, K. (2013). "Physiological and pharmaceutical effects of fenugreek (Trigonella foenum - graecum L.) as a multipurpose and valuable medicinal plant", Global journal of medicinal plant research, 1 (2):199-206.

Narasinga Rao B.S. and Prabhavati, T. (1978). An in vitro 
method for predicting the bioavailability of iron from foods. American J ournal of Clinical Nutrition, 31:169-175.

Rao, Narasimha, Deosthale, Y.G. and Pant, K.C. (2005). Nutritive value of Indian foods. National Institute of Nutrition. Indian Council of Medical Research, Hyderabad, India. 243-444.

Sahai, R. and Gupta, A. (2012). In vitro Bioavailability of iron and nutritional composition of the products prepared from the leaves of the weed, Indian Sorrel (0xalis Corniculata). M.Sc., Thesis of S.H.I.A.T.S., Allahabad, U.P. India.

Sandberg, A.S. (2002). Bioaccessibiltiy of minerals in legumes. Br. J. Nutr., 88: S281-S285.

Sathya, R. Amirthaveni, M. and Vijaylakshmi, P. (2002). Enhancing the bioavailability of iron from mung bean (Vigna radiata L.) through simple modifications in cooking. Ind. J. Nutr. Diet., 39: 45-54.

Singh, G. and Kawatra, A. (2006). Development and nutritional evaluation of recipes prepared using fresh and dried amaranthus (Amaranthus tricolor) leaves. J. Food Sci. Tech., 43 (5): 509-511.

Singh L. Yadav N., Kumar A.R. Gupta A.K. Chacko J. Parvin K. and Tripathi U. (2007). Preparation of value added products from dehydrated bathua leaves (Chenopodium album Linn.). Natural Product Radiance, 6 (1); 45-49.

Srilakshmi, B. (2007). Food Science, $4^{\text {th }}$ Ed., New Age International (P) Ltd., New Delhi : 170-174.

Srivastava R.P. and Kumar, S. (2002). Fruits and Vegetables preservation methods and practices. International book distribution.Co., Lucknow

Tennat, G.B. and Greenman, D.A. (1969). Determination of iron in solutions containing iron complexes. J ournal of Clinical Pathology., 22:201.

Yadav, S. and Sehgal, S. (2002). In vitro and in vivo availability of iron from bathua (Chenopodium album) and spinach (Spinacia oleracia L.) leaves. J . Food Sci. Tech., 39 (1): 42-45. 